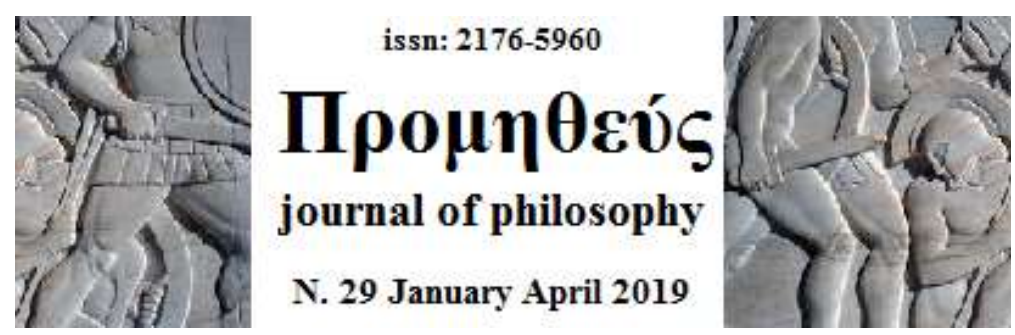

\title{
Index Nominum das Diatribes de Epicteto
}

\author{
Carlos Enéas Moraes Lins da Silva (mestrando UFF)
}

Dr. Aldo Lopes Dinucci (UFS/DFL) ${ }^{1}$

\section{Introdução}

Este trabalho tem o objetivo de fornecer aos possíveis leitores da obra de Epicteto uma ferramenta de auxílio que visa contextualizar com rapidez e praticidade os vários nomes, mitos e histórias citadas pelo autor ao longo da sua rica obra. Este Index é majoritariamente baseado no Index Nominum da rigorosíssima edição de Schenkl (1916) que compreende todo o texto grego, mas também foi consultado o index da tradução inglesa de Oldfather da coleção Loeb de 1925, assim como a edição de George Long de 1890. Desse modo, verificamos as passagens e nomes citados pelo autor, confeccionando entradas explicativas que sintetizam as histórias reais ou os mitos associados a cada nome.

Cremos que essa inédita ferramenta será capaz de proporcionar uma leitura mais compreensiva dos escritos de Epicteto, trazendo seus leitores contemporâneos ao mundo antigo, fazendo-os conhecer os personagens históricos ou mitológicos aos quais Epicteto frequentemente se remete.

Epicteto viveu sob o governo dos seguintes imperadores romanos. Cabe destacar que era amigo e admirado por Adriano, mas que sofre com a era de terror de Domiciano:

\section{Nero (54-68)}

nascimento de Epicteto em aprox. 55.

Galba, Othon e Vitélio (governaram por curto período - 68-69)

\section{Dinastia Flaviana}

Vespasiano (69-79)

\footnotetext{
${ }^{1}$ Aldo Dinucci colaborou revisando o trabalho e indicando alguns complementos, pelo que recebeu a coautoria.
} 
Tito Flávio (79-81)

Domiciano (81-96)

$>$ em 93 Epicteto é exilado em Nicópolis, mesmo ano do julgamento dos opositores estoicos, o que marca o fim do movimento.

\section{Dinastia Antonina}

Nerva (96-98)

Trajano (98-117)

Adriano (117-138)

morte de Epicteto aprox. 135

\section{I- Index Nominum}

Acadêmico, Diss. 1.27.15 - Aquele que aderiu à escola acadêmica de filosofia.

Admeto. Diss. 2.22.11; 3.20 .7 - $\mathrm{Na}$ mitologia grega, foi um rei de Feras, cidade da Tessália, sucedendo seu Pai Feres. Era conhecido pela sua justiça e receptividade, foi escolhido por Apolo como um de seus pastores.

Adônis Diss. 4.8.36 - Ou Adônis. Segundo a mitologia grega, foi um jovem de grande beleza, filho do rei chipreano Círinas com a sua filha Mirra. Tanto Afrodite, deusa grega da beleza, quanto Perséfone, rainha do submundo, passam a disputar o jovem Adônis. Como não se decidiam a um acordo, Zeus instituiu que Adônis teria quatro meses do ano livre passando outros quatro com Perséfone e o restante com Afrodite. No entanto, como Adônis preferia Afrodite acabava passando oito meses com ela, descendo ao Hades apenas o restante para se juntar a Perséfone. Desse mito se originou a ideia do ciclo das plantas que passam quatro meses na terra para nascer após esse tempo. Daí surgiu também o antigo culto de Adonia, celebrado na Grécia.

Adriático (Mar). Diss. 2.6.20 - É o mar que banha o norte e o leste da Itália e o oeste dos Bálcãs. Separava a Itália da antiga região grega do Épiro, na qual se localizava Nicópolis, onde Epicteto se exilou.

Agamenon, Diss. 1.22.5; 1.25.10; 1.28.31; 2.24.21-24; 3.27.7-30; 4.2.10 - Famoso personagem da Ilíada de Homero, Agamenon era irmão do poderoso Menelau e ambos filhos do rei Atreu. Após o rapto de Helena, Agamenon foi o comandante supremo das forças gregas que rumaram a Troia na grande guerra narrada na obra de Homero. É notável a sua arrogância e seu relacionamento conturbado com Aquiles. Apesar de vencer a Guerra, não consegue retornar à pátria, morrendo em Argólida. Histórias envolvendo Agamenon são contadas por muitos tragediógrafos e poetas da Antiguidade, dentre eles, Píndaro, Hesíodo, Homero e Ésquilo.

Agripino, Pacônio, Diss. 1.1.28; 1.2.12 ss; Frag. 21 (56). Estobeu, III. 7, 16; Frag. 22. Estobeu, IV. 7, 44 - Foi um filósofo estoico do séc. I, ao qual Epicteto (apud Estobeu, Serm. 7) se referem com bastante apreço. Seu pai foi condenado à morte por Tibério sob acusação de traição (Suet. Tibério 61). Foi procônsul de Creta e da Cirenaica sob o governo de Cláudio. Foi banido da Itália com Helvídio Prisco e 
Cúrcio Montano por volta de 67 d.C. sob o governo de Nero (Tácito, Anais, 16.27-9, $33)$.

Água Márcia (aqueduto), Diss. 2.16.3031 - O mais longo dos onze aquedutos romanos clássicos.

Ajax, Diss. 2.9.22; 2.24.25 - Na Mitologia grega, é um poderoso guerreiro grego que lutou ao lado de Aquiles a Guerra de Tróia (cf. Juvenal, VX. 65).

Alcibíades, Diss. 1.4.23-30 - (Atenas, 450 a.C. - Melissa, Frígia, 404 a.C.) Foi um proeminente general, orador e homem de estado ateniense. Último membro famoso da família Alcmaeonidae. Desempenhou papel importante na segunda metade da Guerra do Peloponeso. Personagem sempre presente em vários diálogos socráticos.

Alexandre, O Grande, Diss. 2.13.21-27; 2.22.12-18; 3.22.92; 3.24.69-70 - Ou Alexandre III da Macedônia. Foi o famoso conquistador responsável pela ampla difusão da cultura helênica na atual Europa, Ásia menor e norte da África. Alexandre nasceu por volta de 356 a.C. em Pela, era filho do rei macedônio Filipe II. $\mathrm{Na}$ Diss. 2.22.12-18, Epicteto trata da ocasião em que Alexandre manda queimar o templo de Esculápio porque havia perdido seu homem amado, considerandoo um obstáculo aos seus interesses exemplo de homem que ama mais os próprios interesses do que respeita aos deuses. Na Diss. 3.24.69-70, Epicteto cita Alexandre entre Filipe, Pérdicas e "o rei da Pérsia", como exemplo de homens que, apesar do enorme poder, são incapazes de controlar tanto aquilo que está sob a responsabilidade individual quanto o que não está.

Andrômaca, Diss. 3.22.108 - Esposa de Heitor de Troia. Após a derrota na guerra, o filho de Aquiles, Neoptolemo, toma Andrômaca para si e com ela tem 3 filhos.
Anfiarau. Diss. 2.22.32 - Adivinho da corte de Argos, casado com Erífila, irmã do rei Adrasto ( $c f$. Homero, Odisseia, VX. 238-255). Tenta inutilmente dissuadir seu cunhado de empreender uma guerra contra Tebas, tendo visualizado o fracasso de tal empresa.

Ânito, Diss. 2.2.15; 3.23.21, Ench. 53 - (c. 5 - 4 séc. a.C.) Foi um político ateniense. Serviu como general na guerra do Peloponeso e se opôs à tirania dos Trinta. É principalmente conhecido por ter sido o mais influente e formidável dos acusadores de Sócrates (cf. Plat. Apol. 18b.; Hor. Sat. 2.4. 3.).

Antígono, Diss. 2.13.14-15 - Antígono II Gonatas (c. 319-239 a.C.) foi um poderoso comandante que solidificou a dinastia antigônida na Macedônia após longo período de caos político, além de ser saudado pela vitória sobre os gauleses. Uma anedota o coloca entre os admiradores de Zenão (Aélio, Varia Historia, ix. 26), a quem visitava toda vez que ia à Atenas. Em D.L. Zenão vii, podemos encontrar uma carta de Antígono para Zenão e sua resposta.

Antíloco, Diss. 4.10.31 - Filho de Nestor, famoso pela beleza e pela habilidade como condutor de bigas. Na Ilíada, foi o encarregado de dar a notícia da morte de Pátroclo ao amigo Aquiles e se sacrificou em batalha para salvar o pai Nestor.

Antípatro, Diss. 2.17.40; 2.19.2-9; 3.2.13; 3.21.13 - Antípatro de Tarso (morto em 130/129 a.C.), um filósofo estoico, discípulo e sucessor de Diógenes e professor de Panécio por volta de 144 a.C. (cf. Cícero. de Divin. 1.3, de Off. 3.12.). Plutarco o coloca como um dos principais filósofos estoicos ao lado de Zenão, Cleantes e Crisipo (cf. de Stoic. Repugnant. 144). Cícero menciona-o como memorável por sua sagacidade. (cf. De Off. 3.12.) 
Antístenes, Diss. 1.17.12; 2.17.35; 3.22.63; 3.24.67; 4.1.114; 4.6.20 - (c. 445 - c. 365 a.C.) Foi um filósofo ateniense, aluno de retórica de Górgias e pupilo de Sócrates. É considerado o principal inspirador do movimento filosófico cunhado como cinismo.

Apolo, Diss. 3.1 .16 -18; 3.1.134; 3.10 .4 Um dos doze deuses olímpicos da mitologia grega, filho de Leto e Zeus. Muito influente na cultura helênica do mundo antigo, Apolo era identificado com o Sol, a luz da verdade. Patrono do célebre Oráculo de Delfos.

Apolônio, Diss. 3.12.17 - Talvez Apolônio de Tiana, um famoso e controverso personagem de origem grega que viveu no séc. I d.C. Sua biografia é contada por Filóstrato em "Vida de Apolônio". Tradicionalmente o consideram um neopitagórico e asceta que realizou durante sua suposta vida milagres e outras obras fantásticas. Sua figura rivalizava com a de Jesus Cristo na época.

Aprila, Diss. 4.1.146 - Provavelmente uma velha e rica mulher dona de escravos.

Aqueronte. Diss. 3.13.15 - O mitológico rio do Épiro, no qual as almas levadas pelo barco de Caronte, o barqueiro do submundo, deixam seus sonhos e desejos que não se realizaram durante a vida.

Aquiles, Diss. 1.11.31; 1.22.5-6; 1.25.10; 1.28.34; 2.23.32; 2.24.21-24; 3.22.7; 3.23.35 - Um dos protagonistas da Ilíada de Homero. Aquiles foi o mais belo e poderoso guerreiro grego a se envolver na guerra de Tróia, segundo o poema o seu corpo era invulnerável por ter sido banhado no rio Estige. Seu único ponto fraco, e razão de sua morte, era o calcanhar.

Argos, Diss. 3.22.103 - Gigante mitológico de mil olhos, servo da deusa Hera, incumbido de tomar conta da princesa Io. Em 3.24.14, 3.26.31 se trata da cidade de Argos.
Arícia. Diss. 1.1.30 - Cidade próxima à antiga Roma, era a primeira parada dos viajantes que deixavam a Cidade Eterna.

Aristides de Mileto, Diss. 4.9.6 - (séc. 2 a.C.) É reconhecido como inventor do romance grego. Sua obra, a Milésica

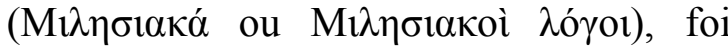
escrita em prosa e possuía um caráter licencioso e, além disso, se passava na cidade de Mileto - possível motivo para o título.

Aristófanes, Diss. 4.11 .20 - (ca. 447 a.C. - ca. 385 a.C.) Foi o maior representante da comédia grega. Autor de várias peças na antiguidade (40 no total, ainda que apenas 7 tenham chegado até nós), dentre elas a mais famosa parece ter sido As Nuvens, na qual acusa Sócrates de exercer má influência na sociedade ateniense.

Arquedemo, Diss. 2.4.11; 2.17.40; 2.19.9; 3.2.13-15; 3.21 .7 - Arquedemo de Tarso foi um filósofo estoico (D. L. 7.40, 68, 84, 88) que floresceu em 140 a.C. Dois dos

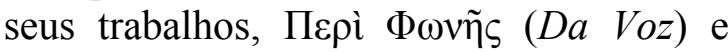

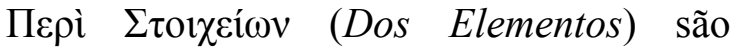
mencionados por Diógenes Laércio. (7.55). Arquedemo parece ser a mesma pessoa à qual Plutarco (de Exilio, 605) chama de um ateniense que, segundo ele, adentrou no território Parta e estabeleceu uma sucessão estoica na Babilônia. Cícero (Acad. Quaest. 2.47), Sêneca (Cartas 121) e outros autores antigos também o citam. No entanto, W. A. Oldfather mantém em aberto a possibilidade de Epicteto estar se referindo a um retórico que comentou uma porção da Retórica de Aristóteles (Quintiliano, IIL 6. 31 e 33), sendo estes dois personagens bem distintos (OLDFATHER em nota, p. 237).

Arquelau, Frag. 11 (2). Estobeu, IV. 33, 28 - Arquelau (morto em 399 a.C.), rei da Macedônia de 413 a 399 a.C. De acordo com Platão, sendo ele um filho ilegítimo de Pérdicas II, obteve o trono assassinando seu tio Alcetas, seu primo e seu meioirmão (Plat. Gorg. 471; Ael. VH 12.43), 
mais adiante se consolida através do matrimônio com Cleópatra, a viúva de seu pai (Plat. Gorg. 471c.; Aristot. Pol. 5.10)

\begin{abstract}
Arquidamo II, Diss. 4.1.156 Acreditamos ser Arquidamo II, um rei euripontida de Esparta que reinou aproximadamente de 476 a.C. a 427 a.C. Arquidamo II ascendeu ao trono depois que seu avô fora banido sob acusação de corrupção, por volta de 476 a.C. Foi durante seu governo que toda a região da Lacônia (onde se localizava Esparta) sofreu a ação de um terremoto. Na ocasião se diz que sua presença de espírito salvou o estado espartano, mesmo que a cidade tenha sido reduzida a ruínas. Em 446 a.C. chega a um acordo com Péricles que deu origem aos Trinta anos de Paz entre Atenas e Esparta.
\end{abstract}

Arriano, Frag, 9. (180). Gélio, XIX. 1, 14-21, Frag. 10. (179). Gélio, XVII. 19 Lúcio Flávio Arriano Xenofonte da Capadócia (Lucius Flavius Arrianus): ca. 90-175 a.C. Filósofo estoico, historiador e aluno de Epicteto. Ele foi pupilo e amigo de Epicteto. Através da influência do seu mestre, ele se tornou um zeloso e ativo admirador da filosofia estoica e mais especialmente da parte prática do seu sistema. Ele primeiro atraiu a atenção enquanto filósofo ao publicar as Diatribes $(\delta 1 \alpha \tau \rho \imath \beta \alpha i ́)$ do seu mestre. Parece tê-la publicado em Atenas. Os atenienses ficaram tão encantados que o honraram com sua cidadania. Arriano escolheu Xenofonte como um modelo de escrita, por isso, era chamado de jovem Xenofonte, talvez pela semelhança de estilo com o grande historiador grego, mas também pela similaridade entre a sua conexão com Epicteto e aquela conhecida relação de Xenofonte e Sócrates. (Fócio, p. 17b. ed. Bekker; Suidas, s. v. Appıavós.). Em 136 d.C., ele foi nomeado Prefeito da Capadócia, invadida um ano antes pelos Alanos. Ele defendeu o território em uma batalha decisiva, juntando a sua reputação de filósofo à de bravo e hábil general. Sob
Antônio Pio, sucessor de Adriano, Arriano foi promovido a Cônsul, em 146 d.C. Em seus últimos anos parece ter se retirado da vida pública, e aproximadamente a partir de 150 d.C. voltou a viver em sua cidade nativa (Nicomédia) como sacerdote de Deméter e Perséfone, devotando-se inteiramente ao estudo e composição de obras históricas. Morreu com idade avançada sob o império de Marco Aurélio. Se diz que Dion Cássio escreveu uma biografia de Arriano pouco após sua morte, mas nenhuma parte da obra chegou até nós (Suid. s. v. $\Delta i ́ \omega v$.)

Artaxerxes (III) Oco, Diss. 4.1.27-33 (ca. 425 a.C. - 338 a.C.) Provavelmente "o Rei Persa" citado por Epicteto. Filho de Artaxerxes II, foi o décimo xá do Império Aquemênida. Antes de subir ao trono foi um sátrapa responsável pelo exército do pai sendo conhecido por reprimir a Revolta dos Sátrapas em 367-362 a.C. Se casou com a própria sobrinha, filha de Oxatres, irmão do futuro rei Dario III da Pérsia. Seus filhos foram Arses, o futuro rei da Pérsia, Bistanes e Parísatis, que se tornou esposa de Alexandre, O Grande.

Asclépio, Diss. 4.8.29 - Esculápio ou

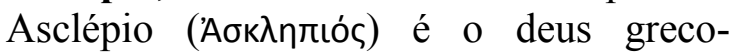
romano da medicina e da cura. Filho do deus Apolo com a humana Corônis. Logo após seu nascimento foi levado para ser criado pelo centauro Quíron, com o qual aprendeu a arte da cura.

Atena (Palas), Diss. 2.8.18-20; 2.19.26; 3.13.4 - As duas primeiras passagens tratam apenas de Atena enquanto motivo das estátuas do lendário escultor Fídias ( $c f$. Fídias abaixo). Atena, ou Palas Atena, é considerada a deusa da civilização, da sabedoria, da estratégia em batalha, das artes, da justiça e da habilidade. Umas das divindades gregas mais importantes entre os doze deuses olímpicos. Exerceu grande influência na cultura da antiguidade clássica, sendo cultuada nas mais diversas 
cidades antigas (sobretudo na cidade de Atenas) - incluindo também o império romano, no qual assume o nome de Minerva.

Ática. Diss. 2.16.45 - Antiga região da Grécia que englobava Atenas.

Atreu. Diss. 1.28.32 - Na mitologia grega, era o rei de Micenas, pai de Agamenon e Menelau.

Automedonte, Diss. 4.10 .33 - Condutor da biga de Aquiles e Pátroclo que se torna companheiro de Aquiles após a morte de Pátroclo.

Bárea Sorano (alusão), Diss. 4.1.138-145 - Possivelmente relacionado a uma alusão a Inácio Celer, que acusou seu amigo, Barea Sorano, durante o reinado de Nero, 66 d.C., quando Epicteto era menino ( $c f$. Tácito, Anais, 16, 32, e Juvenal 3, 116f). Sorano era consul suffectus em 52 d.C., sob governo de Cláudio, e posteriormente procônsul da Ásia. Pela sua justiça e zelo durante a administração da província ele despertou o ódio de Nero, sendo acusado por Ostório Sabino, um guerreiro romano, em 66 d.C. As acusações contra ele tratavam da sua intimidade com Rubélio Plauto e da suposta elaboração de ganhos da província da Ásia com a proposta de revolução. Tanto Sorano quanto sua filha foram condenados à morte e lhes coube escolher o modo de execução. A principal testemunha contra o pai e a filha foi P. Inácio Celer, um filósofo estoico, antigo cliente e também professor de Sorano. Um ato de vilania a que Juvenal alude (3.116) "Stoicus occidit Baream, delator amicum, discipulumque senex" (O estoico que matou Bárea, delator amigo, velho discípulo). Inácio recebeu grande gratificação de Nero, mas posteriormente foi acusado por Musônio Rufo sob o governo de Vespasiano e condenado à morte (Tac. Anais 12.53, 16.21, 23, 30-33, Hist. 4.10, 40; Dion Cass. I.xii. 26; ad Juv. $1.33,6.551$.
Batão, Diss. 1.2.26 - um treinador de gladiadores da época de M. Aurélio.

Briseida, Diss. 1.25.10 - Personagem da Ilíada sequestrada durante a guerra por Aquiles, restituída à sua terra por Agamenon em razão de um oráculo.

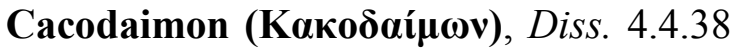
- Adjetivo que significa "o que possui um mau gênio", epíteto de Sócrates nas Nuvens de Aristófanes (Ar. Nu. 104).

Cálicles, Diss. 4.5 .3 - (c. 484 - fins do 5 séc. a.C.) Foi um filósofo e político ateniense, especialmente lembrado por sua representação no Górgias de Platão.

Cássio Longino, Diss. 4.3.12 - Distinto jurista romano da primeira metade do século primeiro d.C., descendente de Caio Cássio Longino, um dos assassinos de Júlio César. Cássio, um pupilo de Sabino, era escolarca da escola jurídica dos Sabianos ou Cassianos. Seus principais trabalhos são o libri (commentarii) iusris civilis em, ao menos, 10 volumes, os quais sobreviveram em citações de autores posteriores como Iavoleno. Ele foi pretor e consul suffectus em 30 d.C., além de procônsul da Ásia menor em 40-41 d.C. e legado da Síria em 41-49 d.C. Foi exilado por Nero à Sardenha em 65 d.C. e retornou à Roma sob Vespasiano.

Cassiopeia, Diss. 3.7.3 - Personagem mitológico, mãe da princesa Andrômeda. Vaidosa e arrogante, se dizia mais bela que as nereidas. Após algumas peripécias, foi punida, sendo transformada na constelação homônima.

César, 1.2.23-24; 1.2.3; 1.9.7; 1.10.5; 1.14.15; 1.19.17-19; 1.29.37-61; 2.6.20; 2.13.11; 2.19.17; 3.4.2-3-7-8-24; 3.7.30; $3.8 .2 ; 3.9 .18 ; 3.13 .9-12 ; 3.15 .12 ; 3.22 .55-$ 56 ; 4.1.8-12-14-15-17-43-45-46-47-48-49$60-95 ; 4.4 .5 ; 4.7 .21 ; 4.13 .5$ - Epíteto usado para designar diferentes imperadores romanos. 
Ciro, Diss. 4.6.20 - Esse mesmo trecho é citado posteriormente por Marco Aurélio em Med. vii. 36. É algum interlocutor possivelmente real (no sentido de realeza) de Antístenes neste célebre dito. Sabemos que Antístenes tem uma obra chamada Ciro, cujo conteúdo só temos notícia de que se trata de um ataque a Alcibíades. (ver Antístenes acima).

Cleantes, Diss. 1.17.11; 2.19. 5-9-14; $3.23 .32 ; 3.26 .23 ; 4.1 .173 ; 4.4 .34$; citado em 2.23.42; 3.22.95; 4.1.131; Ench. 53 Cleantes de Assos (ca. 330 a.C.- ca. 230 a.C.) segundo escolarca do Pórtico, aluno, amigo e sucessor de Zenão.

Cnossianos, Diss. 3.9.3-6 - habitantes de Creta.

Cócito, (Кюкvтós), Diss. 3.13.15 - O rio das lamentações do Hades, o submundo.

Coré ou Cora (Kóp̀̀), Diss. 2.20.32 - A filha de Deméter, também chamada de Perséfone

Crates (tebano), Diss. 2.22.63-73 Filósofo cínico do séc 4 a.C., reconhecidamente um seguidor de Diógenes. Floresceu, de acordo com Diógenes Laércio (6.87), em 328 a.C. Estava ainda vivendo em Atenas no tempo de Demétrio de Falero (Atenas. 10.422c.; D. L. 6.90), e estava em Tebas em 307 a.C., quando Demétrio de Falero deixou esta cidade. (Plut. Mor. p. 69c.). Assim como Diógenes, Crates foi conhecido por seguir o modo de vida cínico, sendo também ele personagem de várias anedotas.

Creso, Diss. 1.2.37, 2.22.27 (Kpoĩøos, Kroisos; 595 a.C. - c. 546 a.C.) Foi um descendente de Giges, do clã mirmidão, que assumiu o poder quando Giges matou Candaules (Cf. Heródoto, Histórias, livro I). Foi um rei da Lídia que, de acordo com Heródoto, reinou por 14 anos, iniciando seu governo em 560 a.C. até a sua derrota para o rei persa Ciro em 546 ou 547 a.C. Existem três versões de histórias sobre Creso: Heródoto apresenta as versões lidianas da conversação com Sólon (Histórias 1.29-.33), a tragédia do filho de Creso, Ates (Histórias 1.34-.45) e a queda de Creso (Histórias 1.85-.89) Xenofonte exemplifica Creso em sua biografia panegírica de Ciro (Ciropédia, 7.1)

Crinis, Diss. 3.2.15 - Um filósofo estoico de pouca proeminência que se supõe ter morrido de um choque apoplético ocasionado por um susto ao ver um rato descendo pela parede. Foi várias vezes referido por Diógenes Laércio $(7.62,68$, 76) e parece ter fundado uma escola independente dentro dos limites do sistema estoico, já que a autoridade dos seus

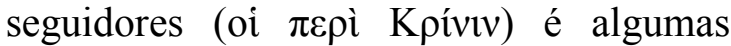
vezes citada. Escreveu um trabalho

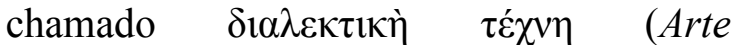
Dialética), do qual D.L (7.71) cita uma opinião.

Crisantas, Diss. 2.16.15 - Foi um nobre persa, recordado por Xenofonte como um homem de superiores poderes da mente e inferior estatura corporal (Cirop. 2.3.5.) Foi representado ao longo da Ciropédia como merecedor de alto valor em favor de Ciro, a quem se provou o mais útil, não apenas por sua prontidão e galanteria no campo de batalha, mas também pela sua sabedoria no Conselho e zelo com o qual encaminhou os planos políticos do príncipe. Na distribuição das províncias, depois da conquista da Babilônia, seus serviços foram recompensados, de acordo com Xenofonte (Heródoto. 1.153), com a satrapia da Lídia e Iônia. (Xen. Cirop. 2.2.17, \&c., 3. §§ 5-7, 4.22, \&c., 3.1. §§16, 3.48, \&c., 4.1. §§ 3, 4, 3. §§ 15-23, 5.3.6, 6.2. $\S \S 21,22,7.1 .3,5 . \S \S 55,56$, 8.1.1, \&c., 4.9, \&c., 6. 7.)

Criseida, Diss. 1.22.7-8; 2.25.21 - Presa de guerra tomada por Agamenon, teve de ser devolvida após uma maldição (Cf. Ilíada, I). 
Crisipo, Diss. 1.4.6-7-9-14-28; 1.10.10; 1.17.11-13-15-17-18; 2.6.9; 2.17.34-40; 2.19.5-9-14; 2.23.44; 3.2.13; 3.24.81; 4.9.6; Frag. 9 (180). Gélio, XIX. 1, 14-21, Ench. 49 - Crisipo de Solis (ca. 280 a.C. - ca. 208 a.C.) Considerado o segundo fundador do Pórtico e terceiro escolarca. Em Atenas foi discípulo de Cleantes na escola estoica. Quando este morreu, por volta de 230 a.C., Crisipo assumiu o posto de escolarca. As contribuições de Crisipo nas diversas facetas da doutrina estoica são incomensuráveis e fazem dele um dos mais importantes filósofos estoicos de todos os tempos.

Críton, Diss. 4.1.163, Ench. 53 Personagem do diálogo platônico homônimo. O diálogo em questão trata do debate entre Sócrates e o rico Críton acerca da justiça e da injustiça.

Culto Imperial a Augusto, Diss. 1.9.1928 - Cremos ser Otávio Augusto, o fundador do primeiro principado de Roma, o que abriu portas para o império.

Dânao, Diss. 3.22.78 - Um ancestral mitológico dos gregos primitivos, os dânaos, que viviam em Argos. Dânao, ou $\Delta \alpha v \alpha o ́ s$, foi um dos filhos de Anquínoe e Belo, um rei mítico do Egito descendente da sacerdotisa de Hera, Io.

Dêifobo, Diss. 2.19.7 - Membro da família real troiana na Ilíada de Homero. Filho de Hécuba e Príamo, e irmão de Páris e Heitor. Notavelmente, na intriga da Ilíada, Dêifobo toma como esposa a viúva do irmão Páris, Helena. Ao fim da Guerra de Troia, Menelau acaba com a vida de Dêifobo.

Deméter, Diss. 2.20.32; 3.21 .12 - É uma deusa grega olímpica, filha de Cronos e Reia. Deméter era a deusa da agricultura e da terra cultivada, controlava as colheitas e as estações do ano. Junto a Dionísio fez longas viagens a fim de ensinar os homens a cultivar a terra. Seu culto estava associado aos famosos Mistérios de Elêusis. (cf. Elêusis, abaixo)

Demétrio, Diss. 1.25.22 - Foi um filósofo cínico que nasceu em Corinto, mas viveu em Roma durante os governos de Calígula, Nero e Vespasiano. Frequentemente citado por Sêneca (Sêneca, Cartas, 20.9., 62.3., 67.14., 91.19.; De Beneficiis, vii. 1-2, 811). Um curioso fato é que temos notícia dele novamente no reinado de Vespasiano (c. 70 d.C.), quando, inopinadamente defendeu Públio Inácio Céler contra as acusações levantadas contra ele por Musônio Rufo (Tácito, Histórias, 4.40).

Demóstenes, Diss. $2.23 .44-\Delta \eta \mu о \sigma \theta \varepsilon ́ v \eta \varsigma$ (384-322 a.C.) foi um estadista e orador ateniense. Reconhecido pelo Cânon alexandrino como um dos dez maiores oradores e logógrafos áticos, e admirado por figuras marcantes da antiguidade como Quintiliano, Cícero e outros. Se opôs ao domínio macedônio de Atenas durante os governos de Filipe II, Alexandre. Suicidase enquanto era cassado por Antípatro.

Dio (Crisóstomo), Diss. 3.23.17-19 - Dio Crisóstomo, de Prusa, (ca. 40 - Prusa, ca. 120 d.C.) foi um orador, escritor, filósofo e historiador grego do séc. I do império romano. Ele também carregava o sobrenome Cociano (Plin. Epist. 10.85, 86), o qual proveio do imperador Coceio Nerva, com quem se conectava por íntima amizade (Orac. xiv. p. 513.). Inicialmente permaneceu em sua terra natal, onde realizou importantes trabalhos, como a composição de ditos e outros ensaios sofístico-retóricos, mas ao perceber a futilidade desse tipo de ocupação, abandonou-a e passou a devotar-se com grande zelo ao estudo de filosofia. Seu objetivo era aplicar as doutrinas da filosofia às propostas da vida prática, e mais especialmente à administração dos negócios públicos, e então trazer à tona um melhor estado de coisas. Foi contemporâneo de Epicteto. 
Diodoro (Crono), Diss. 2.19.1-5 - O filósofo e dialético Diodoro Crono (morto em 284 a.C.) conhecido por ser conectado à escola megárica e também por ter proposto o argumento mestre em resposta à discussão aristotélica dos futuros contingentes.

Diógenes da Babilônia, Diss. 2.19.14 Diógenes da Babilônia (ou da Selêucia) (ca. 230 a.C.-ca. 150/140 a.C.) foi o quarto escolarca do Pórtico, um dos três filósofos enviados a Roma em 155 a.C. numa missão diplomática. Professor de Panécio e Antípatro, ensinou lógica a Carnéades, com quem foi, junto com Critolau, a Roma apelar quanto ao pagamento de uma multa de 100 talentos (DINUCCI \& FONTES, 2016).

Diógenes, o Cínico, Diss. 1.24.6-9; 2.3.1; 2.13 .24 ; 2.16.35; 3.2.11; 3.21.19; 3.22.2457-63-80-88-91; 3.24.40-64; 3.26.23; 4.1.30-114-152-156; 4.7.29; 4.9.6; 4.11.21; Ench. 15 - Diógenes de Sínope (Sínope, 404 ou 412 a.C. - Corinto, c. 323 a.C.) foi um notável personagem da filosofia ocidental, sendo conhecido principalmente pelo modo de vida alinhado a filosofia cínica, narrado nas diversas anedotas que colorem obras de toda tradição da antiguidade, sendo um dos maiores representantes da escola.

Dióscuros, Diss. 2.18.29 - Coletivo que designava os irmãos gêmeos Castor e Pólux que se tornaram imortais. Segundo o mito, os dois irmãos eram filhos da mesma mãe, Leda, mas Pólux era filho de Zeus e Cástor, filho de Tíndaro. Por isso, o primeiro era imortal enquanto o segundo, não. Quando Cástor morreu, Pólux pediu ao pai que fizesse do irmão imortal também e assim eles se tornaram estrelas, dando origem à constelação de Gêmeos. Os Dióscuros se tornaram padroeiros dos navegantes. Para eles, duas aparições do Fogo-de-Santelmo, era sinal dos dois irmãos e indicava que a tempestade iria findar-se.
Dirce, Diss. 2.16.30 - Uma fonte da antiga cidade de Tebas cujo nome se refere à história da ninfa Dirce.

Domiciano, Diss. 2.7.8 - Imperador romano no período entre os anos 81- 96 d.C. O último dos Flavianos. Foi durante o seu reinado que Epicteto e outros filósofos foram exilados de Roma por um édito de sua autoria em 93 d.C. Muitas fontes clássicas o descrevem como um imperador tirânico e cruel, cujas deliberações lembravam imperadores como Nero e Calígula.

Ecbátana, Diss. 2.16.35 - Antiga capital de império medo que foi tomada por Ciro, o grande, em 549 a.C.

Édipo, Diss. 1.4.25; 1.24.18; 1.28.32; Frag 11 - Édipo é o personagem de pelo menos três tragédias de Sófocles. Édipo foi o mitológico rei de Tebas que acidentalmente matou o próprio pai e se casou com a própria mãe, sendo vítima de uma antiga profecia.

Egípcios, Diss. 1.11.12-13; 1.22.4; 2.9.20; 2.11.15 - Naturais do Egito.

Elêusis, Diss. 3.21.13 - Era uma antiga cidade grega próxima a Atenas, na qual se realizavam famosos ritos de culto a Deméter e Perséfone, duas deusas ligadas ao cultivo agrícola, os chamados Mistérios de Elêusis.

Éolo, Diss. 1.1.16; 2.22.78 - O guardião dos ventos na mitologia grega ( $c f$. Homero, Odisseia, 10.1-12).

Éolo. Diss. 1.16; 3.22.78 - É o mitológico guardião dos ventos.

Epafrodito, Diss. 1.1.20; 1.19.20; 1.26.11 - Foi o liberto favorito de Nero, empregado como seu secretário. Epafrodito assistiu e acompanhou Nero em seu suicídio após a conspiração que derrubou seu governo, foi este também o motivo da sentença de morte de Epafrodito. Acredita-se que este tenha sido também o senhor de Epicteto. 
Epaminondas, Diss. 3.22.78 - Foi um general e homem de estado tebano do sec. 4 a.C. (ca. 418 a.C. - 362 a.C.), conhecido por ter livrado Tebas do controle espartano e mudado o mapa político da Grécia, transformando Tebas numa potência. Ele venceu as forças militares espartanas em Leuctra. Considerado por Cícero "o primeiro homem da Grécia", e por Montaigne um dos três homens mais dignos e excelentes que já viveram (Ensaios, Livro II cap. 36). As mudanças geradas por Epaminondas sobre a ordem política grega não ultrapassaram a duração da sua vida, enquanto $o$ ciclo de mudanças de hegemonias e alianças permaneceram inabaladas. Vinte e sete anos após sua morte, uma Tebas recalcitrante foi obliterada por Alexandre, o Grande. Assim, Epaminondas - que era clamado em seu tempo como um idealista e libertador atualmente é lembrado por uma década de campanhas (371 a.C. a 362 a.C.) que derrubaram a força dos grandes poderes terrestres da Grécia e abriram caminho para a conquista macedônica. Morreu em batalha na Mantineia, contra os espartanos, com um lança no tórax. Perto da morte, no acampamento, quando perguntou quem venceu a batalha respondem-no que foram os beócios, pelo que pensou Epaminondas ter morrido vitorioso.

Epicárpio (Zeus), Diss. 1.19.12; 1.22.16epíteto de Zeus. ( $c f$. Zeus abaixo).

Epicteto, Diss. 1.1.10; 1.2.29; 1.2.36; 1.9.12; 1.10.4; 3.1.12-36; 3.9.12-14; 3.18.17; Frag 26; G 15 - Epicteto de Hierápolis (55-135 d.C.) foi um notável filósofo estoico de quem nos chegaram uma obra incompleta e diversos fragmentos. Foi pupilo do célebre estoico romano Musônio Rufo. Fundou uma escola em Nicópolis, onde permaneceu até sua morte.

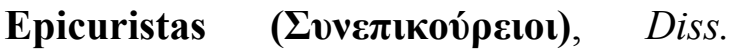
2.20.13 - (ver Epicuro)

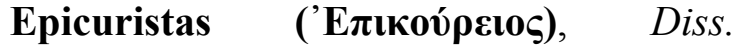
2.19.20-22; 3.7.1-19; 3.24.38; 2.20(tít.); 3.7(tít.) - Aqueles que seguiam os ensinamentos de Epicuro. (ver Epicuro)

Epicuro, Diss. 1.20.17-18; 1.23.1; 2.9.19; 2.20.6-26; 2.22.21; 2.23.21; 3.78.12; Frag. 147 - Epicuro de Samos (342 a.C., Samos - 271 ou 270 a.C., Atenas) foi um pensador grego do período helenístico fundador do movimento filosófico chamado epicurismo.

Erifila ou Erifile, Diss. 2.22.53 Personagem mitológico. Irmã de Adrasto, rei de Argos, era casada com Anfiarau, famoso adivinho. Por almejar o colar da Harmonia (a ela dado por Polinice), convenceu seu marido de participar da guerra contra Tebas, mesmo sabendo que ele morreria.

Erínias, Diss. 2.20.17 - Eram deusas gregas responsáveis por castigar os mortais que viviam nas profundezas do Tártaro. Eram Tisífone (Castigo), Megera (Rancor) e Alecto (Inominável).

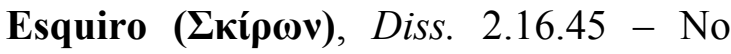
mito de Teseu, é um dos bandidos (um dos outros é Procrustes) mortos pelo herói no caminho de Toezen a Atenas. O corintiano Esquiro roubava viajantes que passavam pelo caminho da Ática e Megaris.

Estoico(s), Diss. 1.29.56; 2.9.19; 2.19.1921-22-23-24; 2.20.12; 3.7.17; 3.24.41 Adeptos dos ensinamentos da escola estoica.

Eteócles, Diss. 2.22.32; 5.4.29; Ench 31 $\mathrm{Na}$ mitologia grega, foi um rei de Tebas, filho de Édipo e Jocasta. E pai de Laodamante. Irmão de Polinices, Antígona e Ismênia. Ele participou do episódio conhecido como Sete contra Tebas.

Eufrates (filósofo), Diss. 3.15.8 (= Ench. 29); 4.8.17 - Um eminente filósofo estoico do tempo do imperador Adriano. Sua procedência é incerta, apesar de haver vastos testemunhos acerca disso 
(Filóstrato. Vit. Soph. 1.7, Vit. Apoll. 1.13). Quando Plínio, o Jovem, serviu na Síria, se tornou familiarizado e parece ter se tornado amigo de Eufrates. Em uma de suas cartas (Epist. 1.10) ele nos dá um detalhado relato das virtudes e talentos de Eufrates. Sua habilidade como orador é reconhecida por outros contemporâneos (Arriano, Diss. Epict. 3.15, 4.8; M. Aurél. 10.31), embora Apolônio de Tiana acuse-o de avareza e lisonja servil. Quando alcançou idade avançada, e já cansado da vida, pediu e obteve de Adriano a permissão para pôr fim à própria vida tomando veneno (Dion Cássio, 69.8.).

Eurípides, Diss. 1.28.32; $2.16 .32 \quad$ Eurípedes foi um importante poeta da Grécia Antiga que nasceu em 485 a.C. na ilha grega de Salamina e morreu em 406 a.C. na cidade de Pela, na Macedônia. Ao lado de Sófocles e Ésquilo, Eurípedes é considerado um dos grandes poetas trágicos gregos, autor de obras consagradas como Electra, Medeia, As Fenícias, As Bacantes, e outros.

Euristeu, Diss. 2.16.44; 3.22.57; 3.26.32 $\mathrm{Na}$ mitologia grega, Euristeu foi um rei de Tirinto e de Micenas, filho de Estênelo e Nícipe. Ele foi encarregado pelo Oráculo de Delfos de exigir de Hércules os Doze Trabalhos como expiação pelo assassinato de seus filhos.

Eveno (de Paros), Diss. 4.9.6 - Um autor erótico do século 5 a.C. admirado por Menandro. (Cf. Arist. Etic. Nic. 7.10.1152a 32; Et. Eud. 2.7.1223a 30).

Febre, Diss. 1.19.6; 1.22.16 - Em Roma, a deusa que personificava a febre, tanto para livrar os febris quanto para causar-lhes o suplício. Tinha pelo menos três templos na Roma Antiga e encarnava a sagacidade e honestidade.

Felício, Diss. 1.19.17-20-21; 4.1.150 - Foi um ex escravo sapateiro de Epafrodito, que o vendeu por considerá-lo imprestável, mas que depois fora comprado por um cesariano e tornou-se o sapateiro de César.

Fênix, Diss. 1.28.32; 2.24.26 - Na primeira passagem é apenas um exemplo de uma phainomenon como outros personagens mitológicos. $\mathrm{Na}$ segunda passagem se trata do velho personagem da Ilíada, famoso por sua eloquência. É possível que na primeira passagem também se trate do mesmo Fênix, mas SCHENKL (1916) assinala para a possibilidade de Epicteto estar se referindo a uma tragédia já perdida de Sófocles, cujo nome também é Fênix.

Fídias, Diss. 1.6.23; 2.8.18-20; 2.19.23-26

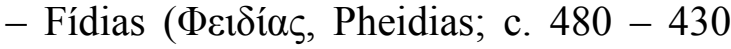
a.C.) era o lendário escultor, pintor $\mathrm{e}$ arquiteto grego, cuja a estátua de Zeus em Olympia, a de Atena na acrópole ateniense (a Athena Parthenos), a colossal estátua de bronze de Athena Promachos, além de Propileu, estão sob seu crédito.

Filipe, Diss. 2.13.24; 3.22.24; $3.24 .70-$

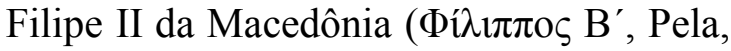
382 a.C. - 336 a.C.) foi rei da Macedônia de 359 a 336 a.C. Epicteto o cita, nessa passagem, juntamente com Diógenes. (ver Diógenes acima)

Filostorgos, Athenais, Diss. 3.17 .4 Atenais, a Amável, rainha da Capadócia por seu casamento com Ariobarzanes I Filoromaios, rei da Capadócia entre 95 e 63/62 a.C.

Floro, Diss. 1.2.12 - É citado em Epicteto em ocasião em que com Agripino sobre participar ou não de um festival de Nero. Possivelmente é Géssio Floro, Procurador romano da Judeia de 64 a 66 d.C. Oldfather $(1928$, p. 18, n.10) crê que a participação de Floro consistiria em representar um papel numa tragédia. (Cf. Tácito, Anais, xiv. 14; Suetônio, Nero, 21).

Galba, Diss. 3.15.14 - Sérvio Sulpício Galba foi um dos quatro imperadores que governaram Roma durante o ano de 69 
d.C. após Nero. De carreira política brilhante, Galba atingiu o consulado em 33 d.C., sendo governador da Germânia e procônsul na África de 45 a 60 d.C. Após a morte de Nero, marcha sobre Roma com o apoio de Otão, sendo proclamado imperador. Contudo, suas políticas impopulares e sua decisão de não propor Otão como seu sucessor fizeram esse último realizar um complô que levou à morte de Galba.

Galileus, Diss. 4.7.6 - Provavelmente os cristãos.

Galos, Diss. 2.20.17 - Eram os sacerdotes eunucos responsáveis pelo culto à deusa Cibele.

Gélio, Lúcio, introdução - A quem Arriano cumprimenta como primeiro texto das Diatribes. Lúcio Gélio Publicola, morto em 54 a.C., foi um praetor peregrinus em 94 a.C., cônsul em 72 a.C. e censor em 70 a.C. Provavelmente parente de Aulo Gélio.

Getas, Diss. 4.1 .19 - É o personagem escravo (um mercenário) da comédia de

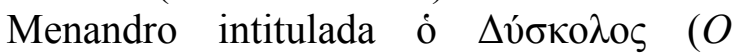
Misantropo).

Giaros, Diss. 1.25.19-20; 2.6.22; 3.24.100109-113; 4.4.34 - Famosa ilha que se tornou destino frequente dos exilados romanos, como foi no caso do estoico Musônio Rufo. Famosa por ser isolada e inóspita.

Grande Rei, Diss. 2.22.22; 3.22.60; 3.24.70; 4.1.53 - Para OldFather, se trata do Grande Rei da Pérsia, talvez seja Ciro II que viveu no séc. 6 a.C. e reinou a Pérsia entre 559 e 530 a.C., na época o maior império do mundo. Ele iniciou suas conquistas marchando sob a capital Ecbatana, anexando o império medo. Estabelecendo sua influência política a região do atual Irã, partiu para a conquista da Lídia e de territórios a leste da Pérsia até o Turquestão, na Ásia Central. Como também conquista a Babilônia em 539 a.C.
Ciro governou sabiamente seu vasto reino, mantendo seu poder, mas tolerando as diferenças culturais dos diversos povos que anexou, mantendo uma unidade $\mathrm{e}$ consistência ao seu império.

Gratila, Verulana, Diss. 2.7.8 - É citada por Epicteto ao mencionar a perseverança de uma outra mulher em enviar um barco de provisões a ela. Muito possivelmente seja a cônjuge de Aruleno Rústico, banida por Domiciano no processo de 93 d.C. que condenou ao exílio e à morte outros nomes ligados à chamada Oposição Estoica - no mesmo ano em que Epicteto e outros filósofos são banidos de Roma.

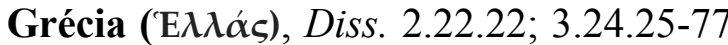
- É, literalmente, a Grécia Antiga.

Hades. Diss. 2.6.18; 3.13.15 - É utilizado por Epicteto exclusivamente no sentido de localidade. É o mundo dos mortos onde habitam as almas daqueles que se foram. Sua entrada e localização são matéria de debate. Segundo a mitologia, a entrada era guardada pelo cão de três cabeças, Cérbero, dócil aos que vinham e feroz aos que pretendiam sair. A entrada distava do interior por conta dos rios de águas violentas que correm dentro do Hades. São eles os famosos Estige, Caronte, Aqueronte, Lete, Cócito e Piriflegetonte. O reino dos mortos pode ser dividido entre os Campos Elísios nos quais viviam os heróis e homens honrados e o Tártaro, lugar das almas infelizes.

Hécuba, Diss. 2.19.7 - Esposa do rei Príamo de Tróia, mãe de dezenove filhos dentre eles Heitor, Páris e Cassandra.

Hefesto, Diss. 4.8.21 - Na mitologia grega é o deus ferreiro, filho de Zeus e Hera. Ao contrário da perfeição física demonstrada pelos outros deuses gregos, Hefesto era manco e tinha uma aparência grotesca. Sua característica principal é a sua habilidade como ferreiro e artesão. 
Heitor, Diss. 2.19.7; 2.24.22-25; 3.22.7 Grande guerreiro troiano filho de Hécuba e Príamo. Heitor assume as forças troianas durante a Guerra de Troia, narrada por Homero na sua Ilíada. Grande guerreiro, assassino de vários heróis gregos, Heitor é apenas suplantado por Aquiles, que o derrota em batalha individual para vingar a morte do amigo Pátroclo.

Helânico, Diss. 2.19.7-14 - Escreveu uma História do Egito. Se for o Helânico de Lesbos, será um logógrafo grego do séc. 5 a.C.

Helena, Diss. 1.28.12; 2.19.10; 2.23 .32 Helena era filha de Zeus com a mortal Leda, tida como filha por Tíndaro, seu padrasto. Helena era considerada a mulher mais bela e, por isso, tinha vários pretendentes, mas acabou por se casar com Menelau, rei de Esparta e irmão de Agamenon. Seu sequestro pelo troiano Páris originou a Guerra de Troia.

Helvídio Prisco, Diss. 1.2.19; 4.1.123 Epicteto cita-o como um homem que mantém o caráter adequado frente ao imperador Vespasiano. É, portanto, favorável a ele. Foi um Senador romano estoico que morreu por volta de 79 d.C. e defendeu avidamente o princípio republicano de que o imperador devia agir apenas com o consentimento do Senado. Embora filho de um centurião, ascendeu ao Senado no governo de Nero e tornou-se pretor em 70 d.C. Mais tarde, sua intransigente liberdade de expressão o levou a entrar em conflito com o imperador Vespasiano, talvez porque ele se opusesse à sucessão dinástica, e foi, por isso, morto. É referido por Tácito (Histórias, iv. 4, 5) como um homem honesto: "Ele seguiu os filósofos que consideram apenas as coisas boas aquelas que são virtuosas, e apenas ruins aquelas que são faltas; e ele reconhecia poder, casta e todas as coisas que são externas à mente como nem más nem boas". Vespasiano, provavelmente movido por paixão, sendo provocado por Helvídio ordena a sua morte e acaba voltando atrás na decisão quando já era tarde demais (Suetônio, Vespasiano, c.5) (ver mais informações em http://www.oxfordreference.com/view/10. 1093/oi/authority.20110803095929901 ).

Hera, Diss. 3.13.4 - Na mitologia grega é a deusa da fertilidade, da maternidade e das esposas. É a esposa e irmã ciumenta de Zeus.

Héracles (Hércules), Diss. 1.6.33; 2.16.44-45; 2.18.22; 3.22.57; 3.24.13; 3.26. 31-32; 4.10.10 - Na mitologia grega é um semideus, filho de Zeus e uma mortal, Alcmena. Famoso pela extrema força e pela perseverança nos famoso Doze Feitos.

Heráclito, Diss. 2.2.17, Ench. 15; alusão em Diss. 2.1 - (aproximadamente 535 a.C. - 475 a.C.) Foi o famoso filósofo présocrático conhecido pela célebre tese mobilista de que "tudo flui" (em grego, $\pi \alpha ́ v \tau \alpha \dot{\rho} \varepsilon \tilde{\imath})$, que rivalizava com as posições defendidas pela tradição Eleata.

Hermes, Diss. 3.1.39; 3.20.12 - Um dos mais antigos deuses olímpicos, filho de Zeus com a deusa Maia. Conhecido por ser o mensageiro dos deuses, era o encarregado de guiar as almas para o reino de Hades. Era também deus da eloquência, das viagens, dos diplomatas e etc.

Hesíodo, Diss. 2.18.32 - Famoso poeta grego, em atividade entre 750 - 650 a.C., comumente reconhecido como o primeiro poeta escrito da tradição ocidental. As três obras mais famosas que são tradicionalmente atribuídas a ele são: $O s$ Trabalhos e os Dias, a Teogonia e $O$ Escudo de Héracles.

Hípias, Diss. 3.5.17 - Um Sofista, nativo de Elis, foi discípulo de um certo Hegesidamo (Suid. s. v.), bem como contemporâneo de Sócrates e Protágoras. Viajou por várias cidades e distritos da Grécia a fim de adquirir riqueza e celebridade, dando aulas e demonstrando 
sua oratória em falas públicas. Seu caráter enquanto sofista, sua vaidade, sua jactanciosa arrogância é descrita em dois diálogos de Platão, o 'I $\pi \pi i ́ \alpha \varsigma \mu \varepsilon i ́ \zeta \omega v$ e o

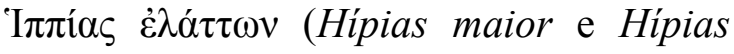
Menor, respectivamente).

Hipócrates, Diss. 1.8.11-12, 2.17 .8 Célebre médico grego antigo $(460$ - c. 370 a.C.), conhecido como o pai da medicina moderna.

Hipólito, Diss. 1.28.32 - Na mitologia grega é o filho de Teseu e Hipólita. Uma tragédia de Eurípedes leva o seu nome.

Homero, Diss. 2.19.7; 3.22.78; 3.24.18; 4.10.36; Ench. 49/cf. 3.1.38; 3.11 .4 Famoso poeta épico grego. Muito pouco se sabe sobre sua biografia, estima-se (Heródoto 2.53) que tenha vivido por volta de 850 a.C. ou 1102 a.C., ou mesmo 1270 a.C.

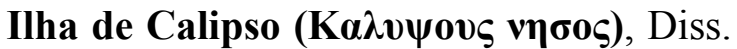
2.19.10 - Ilha na qual a nereida Calipso seduziu Odisseu, detendo-o por longo período (Cf. Homero, Odisseia, 1.14, $1.50)$.

Ilíada, Diss. 1.28.12-18 - Famosa obra de Homero.

Inácio Celer (alusão), Diss. 4.1.138-145 Públio Inácio Celer foi um filósofo estoico sentenciado à morte por Vespasiano por ter sido um informante durante o reinado de Nero. Quando as acusações de traição vieram à tona contra Barea Sorano em 66 d.C., porque ele era objeto de ódio de Nero, Celer (que havia sido professor e cliente de Barea Sorano) foi a testemunha principal contra ele. Sorano fora condenado à morte junto à sua filha Servília. Ignácio recebeu grandes gratificações, depois foi acusado por Musônio Rufo, outro filósofo estoico, sobre Vespasiano, e sentenciado à morte (Tácito, Anais, xvi. 30-33; Juvenal, Sátira iii. 116; Dio Cássio, Ixii. 26). (ver Bárea Sorano acima)
Isócrates, Diss. 3.23.20 - Isócrates foi um célebre retor e orador ático do séc. 5 a.C., que viveu em Atenas entre 436 a.C. e 338 a.C. Isócrates recebeu uma educação privilegiada, entre seus professores estão Tísias, Górgias, Pródico, Sócrates e Teramenes (Dionis. Isocrat. 1; Plut. Vit. X.

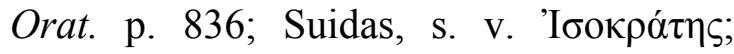
Anonim. Bíos 'Ібокрátovs, in

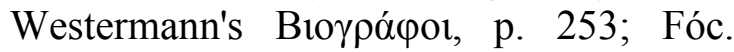
Bibl. Cod. 260.)

Istmia ('I $\boldsymbol{\sigma} \boldsymbol{\theta} \boldsymbol{\mu} \mathbf{\alpha})$ ), Diss. 3.4.11 - Antiga cidade grega localizada no Ístimo de Corinto. Abrigava um templo dedicado a Poseidon. Onde também se realizavam um dos quatro jogos Pan Helênicos realizados na Grécia Antiga.

Itálico, Diss. 3.8.7 - É citado por Epicteto como alguém que não era um filósofo propriamente dito, mas, apesar disso, gozava de certa reputação entre o povo de Roma por fingir ser entendido em filosofia.

Laio, Diss. 3.1.16 - É um mitológico rei de Tebas, personagem principal do mito fundador da cidade de Tebas.

Laterano, Diss. 1.1.19 - Plautio Laterano foi um romano da classe senatorial que viveu durante o séc. 1 do Império. Foi acusado de ter um caso com Messalina, esposa de Cláudio (Tácito, Anais 11:36, e 15:60), mas escapou sob intervenção do seu tio Aulo Plautio, mas morreu e teve os bens confiscados sob o governo de Nero após ser condenado por conspiração na época em que era consul designatus.

Léon (de Sálamina), Diss. 4.1.160; 4.7.30 - Um nativo de Salamis e cidadão de Atenas, foi sentenciado à morte pelos Trinta Tiranos, que ordenaram Sócrates junto a outros quatro, entre os quais estavam Metelo, a trazê-lo de Salamis, onde supostamente havia se retirado para escapar da crueldade e rapacidade do novo governo. Sócrates não executou o comando, ainda que a missão tenha sido levada a cabo pelos outros quatro. A partir 
da fala de Teramenes em Xenofonte, sabemos que Leon era um homem de valor

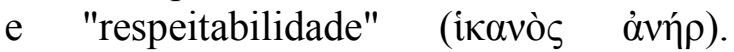
Andocides nos conta que Léon fora condenado sem julgamento. (Xen. Hel. 2.3.39; Plat. Apol. p. 32c, d).

Licurgo, Diss. 2.20.26; Frag. 5 (2). Estobeu, III. 19, 13. Musônio, frag. 39 (H.) - Licurgo de Esparta (c. 900 - 800 a.C.) foi um lendário legislador espartano reconhecido na antiguidade por ter estabelecido a reforma militarmente orientada da sociedade espartana de acordo com o Oráculo de Apolo de Delfos. Suas reformas seguiam as 3 virtudes espartanas: igualdade entre os cidadãos, aptidão militar e austeridade.

Lísias, Diss. 3.23 .30 - Assim como Isócrates, foi um orador ático do séc. 5, nascido em Atenas em 458 a.C. Passou algum tempo em Túrio, na Magna Grécia, onde estudou com os retores siracusanos Tísias e Nícias. Quando retornou a Atenas, grandes infortúnios esperavam ele, pois, durante o governo dos Trinta Tiranos, após a batalha da Egospótamo, foi tido por inimigo do governo. Suas ricas propriedades foram confiscadas e foi enviado à prisão, ameaçado por uma condenação à morte. Porém, escapou de Atenas e se refugiou em Mégara. (Plut. Foc. 11. cc.)

\section{Lúcio (v. Gélio)}

Manes, Diss. 3.26.37 - Era um escravo (o único) de Diógenes, o cínico, que foge do mestre quando ambos aportam em Atenas. $\mathrm{Na}$ anedota que nos chegou, no entanto, Diógenes faz pouco caso e ironiza a situação dizendo: "Se Manes pode viver sem Diógenes, por que Diógenes não pode viver sem Manes?" (cf. Laércio, VI55; Sêneca, De Tranquillitate Animi, 8.7.)

Masúrio, Sabino, Diss. 4.3.12 - Masúrio Sabino foi um distinto jurista romano contemporâneo a Tibério (que reinou entre 14-37 d.C.). Masúrio era um líder dos
Sabiniani, uma escola ou seita de pensamento jurídico dos séc 1 e 2 d.C. O principal trabalho de Masúrio foi um tratado sobre a lei civil (ius civile) em três volumes, os quais tiveram extensa influência. Juristas posteriores, como Ulpiano, escreveram comentários sobre sua obra, mas sem preservar excertos originais.

Máximo, Diss. 3.7.3-10 - Não se sabe ao certo a quem Epicteto se refere. Provavelmente um oficial e administrador romano.

Medeia, Diss. 3.17.19; 4.13.14 - É uma das personagens trágicas mais famosas da literatura clássica ocidental. Segundo a narrativa mais corrente, Medeia foi uma feiticeira que ajudou Jasão e os argonautas em sua jornada, durante esse período ela apaixonou-se por ele, com quem teve dois filhos. Num dado momento Jasão se apaixona por Glauce e deixa Medeia. Diante disso, ela se vinga matando os dois filhos.

Meleto (ver Ânito) - Ateniense citado por Platão na Apologia de Sócrates, Eutífron, Teeteto. Nas Diatribes Epicteto cita-o parafraseando Apologia $30 \mathrm{c}$

Meneceu, Diss. 3.20.5 - Na mitologia grega, foi o rei de Tebas, filho de Creonte e pai de Édipo, morreu segundo a trágica profecia que envolvia seu filho.

Menelau, Diss. 1.28.12-13; 2.22.23; 4.10 .31 - É o mitológico rei da Lacedemônia casado com a bela Helena. O rapto de sua esposa e sua jornada para recuperá-la dão origem à Guerra de Troia (cf. Helena, Páris).

Milo, Diss. 1.2.37 - Milo de Cróton era um lutador do séc. 6 a.C., conhecido por sucessivas vitórias nos mais importantes festivais atléticos da Grécia antiga.

Míron, Diss. 3.22.27 - Em nota, Oldfather diz ser este algum atleta ou gladiador da 
época, juntamente com Ofélio (OLDFATHER p. 139, vol 2).

Mísia, Diss. 1.25.15 - Cidade na qual havia um templo dedicado a Deméter (Paus. VII, 27, 9).

Moiras, Diss. 1.12.25 - Na mitologia grega são as três irmãs míticas, filhas de Moro e Ananke, responsáveis por tecer o fio do destino tanto dos homens quanto dos deuses através da famosa Roda do Destino. São elas: Cloto (a que fia), Láquesis (a que sorteia o lote dos mortais e imortais) e Átropos (a que corta o fio da vida dos mortais).

Naso, Diss. 2.14 (título) - Citado como "um certo cidadão romano" nas Diatribes.

Nemeia, Diss. 3.4.11 - Antiga região grega localizada na parte nordeste do Peloponeso.

Nero, Diss. 1.1.19-20; 1.2.12; 1.25.22; 2.16.31; 3.22.30; 4.5.17, Frag. 21 (9). Estobeu, III. 7, 16 - Nero Cláudio César Augusto Germânico (Anzio, 15 de dezembro de 37 d.C. - Roma, 9 de junho de 68) foi um imperador romano que governou de 13 de outubro de 54, com então 14 anos, até a sua morte. Apesar das vitórias militares, o governo de Nero é recordado pela tirania e pela extravagância. Suas perseguições incluem uma série de execuções emblemáticas, como de sua própria mãe, Agripina, e de seu meio irmão, Britânico. Exilou filósofos como Musônio Rufo. As principais fontes que temos de sua vida são os relatos de Tácito, Dio Cássio e Suetônio.

Numênio, Diss. 3.7.31 - Provavelmente o retor grego Alexandre Numênio, que viveu sob o reinado de Adriano. Nada sobre sua vida é conhecido.

Odisseu, Diss. 1.12.3; 2.24.26; 3.24.13-1820; 3.26.32; Frag 11.12 - É o personagem principal da Odisseia, obra que narra seu conturbado e fantástico retorno para seu reino em Ítaca após a vitória na Guerra de
Troia. Nas aventuras vividas por Odisseu podemos ver ganhar relevo a figura de um herói nem tanto forte e poderoso, mas, especialmente, astucioso.

Ofélio, Diss. 3.22.27 - Ver nota sobre Míron.

Orestes, Diss. 2.20.17 - Na mitologia grega, é o filho de Agamenon e da rainha Clitemnestra. Diante do assassinato de seu pai por parte de sua mãe e seu amante, Egisto, Orestes se exila na corte de seu tio, Estrófio. Já adulto, obedece às ordens de Apolo e mata a própria mãe e Egisto, sendo a partir de então perseguido pelas Erínias.

Pã, Diss. 3.23.11 - Na mitologia grega é o deus dos bosques e dos campos, que vive na floresta rodeado por ninfas tocando sua flauta. Sua figura é associada ao bucolismo camponês e tem a forma física de um misto entre homem e bode, com pernas, orelhas e chifres de bode.

Pantóides, Diss. 2.19.5 - Floresceu por volta de 275 a.C., era um filósofo e dialético ligado à escola megárica. Proeminente em lógica (S.E. A.M. 7.13), foi professor por certo tempo do peripatético Lico de Troades. Escreveu um livro chamado Acerca das Ambiguidades, criticado por Crisipo.

Pátroclo, Diss. 1.11.31; 1.28.24; 4.10 .31 É o personagem da Ilíada de Homero que é primo e talvez amante de Aquiles. Durante a Guerra de Troia, Pátroclo foi morto por Heitor, fato que despertou a vingança de Aquiles.

Penes (Motvaí), Diss. 2.20.17 - Deusas que personificavam a vingança, a punição e a penalidade lançada aos homens culpados pelos homicídios.

Pérdicas, Diss. 3.24.70 - Não está claro nas Diatribes a qual Pérdicas Epicteto está se referindo, já que alguns reis persas receberam esse nome. Talvez se trate de 
Pérdicas I, considerado por Heródoto o fundador da Monarquia Macedônica.

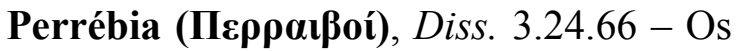
perrebianos eram um povo grego antigo que vivia no norte da Tessália. Eles participaram da Guerra de Troia sob Guneu e também lutaram na Batalha das Termópilas.

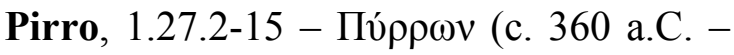
c. 270 a.C.) foi um filósofo grego considerado como um dos primeiros filósofos céticos da tradição ocidental, inspiração para o pirronismo, escola filosófica fundada por Enesidemo no século primeiro a.c. Assim como Epicteto, jamais escreveu.

Pitágoras, Diss. 4.6.32 - Pitágoras de Samos (c. 570 - c. 495 a.C.) foi um filósofo e matemático jônio, líder de um movimento filosófico chamado pitagorismo (em sua homenagem), um tipo de filosofia fortemente influenciada pela matemática. As Pitagóricas são uma coleção de exortações morais vulgarmente atribuídas a Pitágoras, que nada escreveu. Aqui Epicteto faz uma possível paráfrase de um dito de Pitágoras.

Pítia, Diss. 2.20.27 - Ou pitonisa, a sacerdotisa do templo de Apolo, em Delfos.

Pítico, 3.4.11 - Aqui Epicteto se refere aos Jogos Píticos. Era um dos quatro jogos pan-helênicos da Grécia Antiga, este era realizado de quatro em quatro anos na cidade de Delfos, onde, segundo a mitologia grega, Apolo matou a serpente Píton e estabeleceu o oráculo de Delfos. Os outros jogos pan-helênicos eram os de Istmo, Nemeia e os famosos jogos Olímpicos.

Platão, Diss. 1.8.11-13; 1.28.4; 2.17.5-1135 ; 2.18 .20 ; 2.22.36; 4.1.172; Frag. $15-$ (428/427 ou 424/423 - 348/347 a.C.) Foi um filósofo grego fundador da Academia, a primeira instituição de ensino do Ocidente. Sendo considerado um dos mais influentes pensadores da antiguidade.

Plutão, Diss. 2.20.32 - Na Mitologia grega é o deus da riqueza. É o filho da deusa Deméter e o herói Jasio, tem uma forma infantil e o poder de tornar rico a todos que encontra. Para o imaginário de Aristófanes, ele é cego, pelo que não é capaz de distinguir entre as pessoas boas e as más, e é coxo, pelo que demora de chegar, mas alado, porque uma vez tendo chegado logo parte.

Polemo, Diss. 3.1.14; 4.11.30 - Polemo de Atenas (270/269 a.C.) foi um eminente filósofo platônico e o terceiro sucessor como escolarca da academia de 314/313 até 270/269 a.C. Foi pupilo de Xenócrates.

Polinice, Diss. 2.22.13; 4.5.29; Ench 31 É um dos filhos do mitológico rei de Tebas, Édipo. Segundo a tragédia de Eurípedes, ele e seu irmão, Etéocles, rivalizavam para governar a cidade, resolvendo por reinar alternadamente cada um deles. Num dos reinados de Etéocles, Polinices foi expulso de Tebas. O conflito culminou numa guerra civil em que ambos os irmãos morreram.

Polo (sofista), Diss. 4.5.3 - Polo de Agrigento foi um sofista e retor ateniense. Ele foi pupilo de Górgias e escreveu uma obra sobre retórica, denominada por Suidas

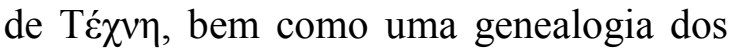
gregos e dos bárbaros engajados na guerra de Troia. É introduzido por Platão como um interlocutor de Górgias.

Polo, Frag. 11 (174). Estobeu, IV. 33 Um famoso ator do quarto século. Sua figura é utilizada por Epicteto para referirse à analogia do teatro, na qual os humanos são os atores e a divindade escolhe o papel de cada um. 
Posidônio, Diss. 1.9.2-8 - Foi um filósofo estoico, político, astrônomo, geógrafo, historiador e professor natural de Apameia, na Síria. Oldfather acredita que Epicteto está citando Posidônio (D.L., VII. 13S) na passagem referida, mas aceita ser essa uma tese comum aos estoicos.

Príamo, Diss. 1.4.25; 2.19.7-10; 3.22.78 Era o rei de Troia quando seu filho Páris sequestrou Helena, esposa de Menelau.

Procrusto, Diss. 2.16.41 - Na mitologia grega, era um homem que vivia no alto de Elêusis. Em sua casa ele tinha uma cama de determinado tamanho na qual os viajantes deveriam se ajustar, caso contrário ele cortava-os ou esticava-os. Acontece que havia na verdade duas camas de tamanhos diferentes, o que resultava que todos os viajantes se tornavam vítimas de suas atrocidades. É vencido apenas por Teseu.

Protágoras, Diss. 3.5.17 - Protágoras de Abdera (Abdera, c. 490 a.C. - Sicília, c. 415 a.C.) foi um eminente sofista grego, principalmente conhecido como personagem de alguns diálogos platônicos.

Quadrato, Diss. 3.23.3 - Várias personalidades distintas com este nome eram contemporâneas a Epicteto. É, no entanto, incerto que algum desses seja o citado, já que eles residiam regularmente em Roma, e esse discurso é ambientado em Nicópolis.

Rufo (Musônio Rufo), Diss. 1.1.27; 1.7.32; 1.9.29; 3.6.10; 3.15.4; 3.20.29; Frag. 4-8 - Caio Musônio Rufo (c. 30-62 d.C.) foi um dos mais proeminentes filósofos estoicos do chamado estoicismo imperial, junto a Epicteto, Marco Aurélio e Sêneca. Foi professor em Roma durante os governos de Nero, sendo exilado em 65 a.C., retornando apenas no governo de Galba, eventualmente banido por
Vespasiano, somente retornando após sua morte. É citado diversas vezes por Epicteto, que foi seu aluno. Sua obra se encontra majoritariamente nos textos de Estobeu.

Sânio, Diss. 3.22.83 - Um nome para o bufão no mime, forma teatral grecoromana (Cic. de Orat. 2.61, ad Fam. 9.16.10).

Sardanapálo, Diss. 3.22.30 - Foi, segundo Ctesias, um dos últimos reis da Assíria que viveu durante o séc. VII a.C. Sua figura é marcada por uma vida ociosa e luxuriosa.

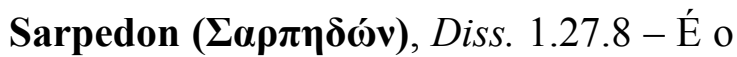
grande rei da Lícia, e filho de Zeus, que luta ao lado dos troianos na Guerra de Troia, morrendo no campo de batalha.

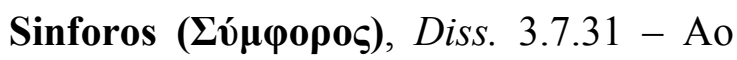
que parece é um rico liberto.

Sócrates, Diss. 1.2.33-36; 1.9.1-22; 1.12.3-23; $1.17 .12 ; \quad 1.19 .6 ; \quad 1.25 .32$; 1.26.18; $1.26 .18 ; \quad 1.29 .16-17-29-65$; 2.1.15-31; 2.2.8-15-18; 2.5.18; 2.6.26; 2.12.5-14; 2.13.24; 2.16.35; 2.18.22; 2.26.6; 3.1.19-21-42; 3.5.14-17; 3.7.34; $3.12 .15 ; 3.14 .9 ; 3.16 .5 ; 3.18 .4 ; 3.21 .19$; $3.22 .26 ; 3.23 .22-25-32 ; 3.24 .38-40-60-99$; $3.26 .23 ; 4.1 .41-123-159-164-169 ; 4.4 .21$ $22 ; 4.5 .2-23 ; 4.7 .29 ; 4.8 .22 ; 4.9 .6 ; 4.11 .12-$ 19; Frag. 11, 28; Ench. 5, 32, 33, 46, 51 (c. 469 a.C. - Atenas, 399 a.C.) Foi um filósofo ateniense do período clássico da Grécia Antiga. Creditado como um dos fundadores da filosofia ocidental, é até hoje uma figura enigmática, conhecida principalmente através dos relatos em obras de escritores que viveram mais tarde, especialmente dois de seus alunos, Platão e Xenofonte, bem como pelas peças teatrais de seu contemporâneo Aristófanes. Muitos defendem que os diálogos de Platão seriam o relato mais abrangente de Sócrates a ter perdurado da Antiguidade aos dias de hoje. 


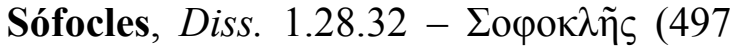
ou 496 a.C.- inverno de 406 ou 405 a.C.) era um dos três grandes escritores trágicos, junto a Ésquilo e Eurípedes. Autor de obras como Antígona, Édipo Rei, Electra e outras.

Sófron, Diss. 3.4.9-11 - Sófron de Siracusa (fl. 430 a.C.) foi um escritor de mimos em dialeto dórico. Sófron foi um autor de diálogos em prosa, contendo tanto personagens femininos quanto masculinos, alguns sérios, outros humorísticos, descrevendo cenas da vida diária dos gregos sicilianos.

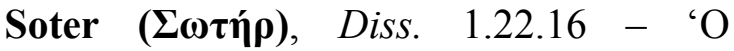
libertador', epíteto de Zeus

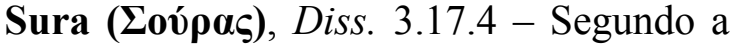
nota da edição de Long, Upton supõe que este seja Palfúrio (Juvenal, iv. 53) ou Palfúrio Sura (Suetônio, Domiciano, c. 13). Palfúrio era um delator e informante de Domiciano, além de ser filho de homem de classe consular. Foi expulso do senado sob Vespasiano, e por isso aplicou-se no estudo de filosofia estoica se tornando bastante eloquente. Retornou ao senado sob Domiciano, enquanto era seu informante, mas, sob Trajano, foi julgado e morto.

Teon ( $\boldsymbol{\theta} \dot{\varepsilon} \omega v)$, Diss. 2.2.23 - Na passagem, ao que parece, não passa de um exemplo de nome.

Teopompo, Diss. 2.17.5-7 - Teopompo de Quios (Quíos, c.378 a.C. - Egito, 323 a.C.) foi um historiador e retórico da Grécia Antiga contemporâneo de Alexandre, o Grande, que, por causa de suas opções políticas e críticas à democracia de Atenas, bem como pela sua preferência ao imperialismo espartano, foi obrigado a exilar-se com frequência de sua ilha natal, Quíos.
Termas de Nero, Diss. 2.16.28-34 Construídas por Nero em 60 d.C. na cidade de Roma.

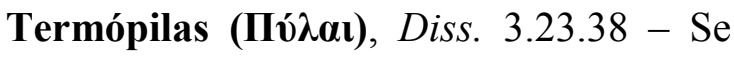
trata de uma citação de Cícero, por parte de Epicteto, na qual Cícero se refere à batalha de Termópilas, na qual a aliança grega formada por espartanos (em terra) e atenienses (por mar) detiveram por sete dias enorme exército persa, liderado por Xerxes I.

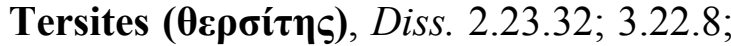
4.2.10 - Tersites, na mitologia grega, era filho de Ágrio, lutou pelos gregos na Guerra de Troia e foi morto por Aquiles após zombar dele.

Teseu, Diss. 2.16.45 - Foi um herói da tradição ática filho de Egeu, que é reconhecido pela extrema força. Suas proezas começaram na infância. A mais conhecida delas é a morte do Minotauro e dos bandidos. (ver também Procrustes e Esquiro).

Trajano, Diss. 4.5.17 - Marco Úlpio Nerva Trajano (18 de setembro de 53 - 9 de agosto de 117) foi o imperador de Roma entre 98 e 117. Em seu governo o império atingiu sua extensão máxima territorial e foi marcado por uma série de benfeitorias.

Trásea, Diss. 1.1.25 - Públio Clódio Trásea Peto foi um Senador romano do Séc. 1 que viveu durante o governo de Nero, ao qual se opunha. Era interessado em estoicismo e mantinha relações com Helvídio Prisco, seu genro. Era casado com Árria, filha da heroica Árria, esposa de Cecina. Foi condenado à morte por Nero sob acusações pouco fiáveis em 66 d.C.

Trasímaco, Diss. 4.5.3 - Um dos três personagens descritos no Banquete de Xenofonte e na República de Platão. Trasímaco de Calcedônia (ca. 459 a.C. - 
400 a.C.) é um dos sofistas antigos, como Górgias, Hípias e Protágoras. Tornou-se professor de retórica e escritor de discursos em Atenas por volta do ano 427 a.C.

Trasônides, Diss. 4.1.19 - Personagem da peça Misoumenos do autor Menandro.

Triptolemo, Diss. 1.4.30 - É uma figura conectada com a deusa Demeter e os Mistérios de Elêusis. Seu culto é relacionado à agricultura.

Vespasiano, Diss. 1.2.19 - Titus Flavius Caesar Vespasianus Augustus (17 novembro $9-23$ junho 79 ) foi um imperador romano que reinou de 69 a 79 d.C. e fundou a Dinastia Flaviana que reinou por vinte e sete anos em Roma. A anedota aqui referida é apenas encontrada em Epicteto segundo MILLAR (1965).

Xantipa, Diss. 4.5.33 - Alusão à insuportável esposa de Sócrates.

Xenócrates, Diss. 4.11.30 - Xenócrates da Calcedônia (c. 396/5 - 314/3 a.C.) foi um filósofo, matemático e líder da Academia platônica de 339/8 a 314/3 a.C.

Xenofonte, Diss. 1.17.12; 2.17.35; Frag. 23.2; citado em 2.12.15; 4.5.3 - Foi um filósofo, historiador e soldado grego. Foi estudante de Sócrates e escreveu a célebre apologia de Sócrates (c. 430-354 a.C.).

Xerxes, Diss. 3.23.38 - Xerxes I (518-465 a.C.) foi o imperador persa de 486 a.C. até a seu assassinato em 465 a.C. Foi um dos quatro reis dos reis da dinastia Aquemênida, filho de Dario e Atossa. O personagem principal da guerra contra os gregos e da famosa batalha das Termópilas. (ver Termópilas acima)

Zenão, Diss. 1.17.11; 1.20.14; 2.13.14-15; 3.21 .19 ; 3.23.38; 4.8.12; 4.9.6; Ench. 33 -

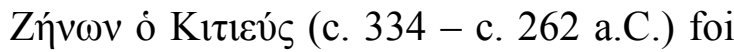
um pensador helenístico de possível ascendência fenícia que estudou filosofia em Atenas e é reconhecido como o fundador do estoicismo.

Zeus, Diss. 1.1.10 -23; 1.3.2; 1.12.25; $1.13 .3-4 ; 1.14 .11 ; 1.19 .9-11-12 ; 1.22 .15-$ $16 ; \quad 1.25 .3 ; \quad 1.27 .8-15 ; \quad 2.8 .18-19-26$; 2.17.22-25; 2.19.25-26; 2.23.42; 3.3.10; $3.4 .7-8 ; 3.7 .36 ; 3.8 .6 ; 3.11 .5 ; 3.13 .4-7$; 3.22.23-34-56-57-82-95; 3.24.16-19-2465-112-117; 4.1.90; 4.4.39; 4.6.5; 4.7.35; 4.8.30-32; sine art: 2.16.44; 2.24.25; 3.11.5; ó Zeus: 1.6.37; né diá: 1.5.5; $1.6 .10 ; 1.7 .26 ; 1.17 .15 ; 1.8 .1 ; 2.18 .7$; 2.12.20-21; 2.20.23-37;2.22.6; 2..23.5; 3.25.3; Frag 8.6; né d. gé: 1.12.6; 1.16.7; 2.16.26; 3.1.29; 3. 21.18; 4.5.15 - É o principal Deus do Olimpo, considerado o "rei dos céus", "Pai dos deuses" dentre outros epítetos que ressaltam a sua proeminência diante dos homens e dos outros deuses, um chefe e ordenador do Universo. Ainda assim, reconhecem-no como o Deus dos Céus e dos relâmpagos.

\section{REFERÊNCIAS:}

DINUCCI, A. \& FONTES, L. M. Lista dos Estoicos Antigos. IN: PROMETEUS, Ano 9, ${ }^{\circ}$ 19, 2016. 
EPICTETO. O Encheirídion de Epicteto. Edição Bilíngue. Trad. Aldo Dinucci; Alfredo Julien. São Cristóvão: EdiUFS, 2012.

EPICTETUS. The Discourses of Epictetus as reported by Arrian; Fragments: Encheiridion. Trad. Oldfather. Harvard: Loeb, 1928.

LIDDELL, H. G. \& SCOTT, R. A Greek-English lexikon. Oxford: At the Claredon Press, 1996.

LONG, G. Discourses of Epictetus, with Encheiridion and fragments. Londres: Georg Bell and sons, 1890.

MILLAR, F. Epictetus and the imperial court. IN: The Journal of Roman Studies, Vol. 55, No. 1/2, Partes 1 e 2 (1965), p. 141-148.

SCHENKL. Epicteti dissertationes ab Arrianos digestae. Lipsia: Teubner, 1916.

SMITH, W. A Dictionary of Greek and Roman biography and mythology. London. John Murray: printed by Spottiswoode and Co., New-Street Square and Parliament Street, 1873. 